\title{
Chemical composition and medicinal potential of Oroxylumindicum:A Review
}

\author{
Sarvesh Kumar ${ }^{1 *} \cdot$ Renu Chaudhary $^{2} \cdot$ Prashant Arya $^{3} \cdot$ Sanjeev Kumar ${ }^{4} \cdot$ Payal Verma $^{5} \cdot$ Navneet \\ Swami $^{6} \bullet$ Vijay Jyoti Kumar ${ }^{1}$ \\ ${ }^{1}$ Department of Pharmaceutical Sciences, H.N.B. Garhwal University (A Central University), Srinagar \\ Garhwal, Uttarakhand, India. \\ ${ }^{2}$ Mahaveer Institute, Meerut (UP) \\ ${ }^{3}$ Department of Microbiology, H.N.B. Garhwal University (A Central University), Srinagar Garhwal, \\ Uttarakhand, India. \\ ${ }^{4}$ MIT institute of technology Meerut (UP) \\ ${ }^{5}$ SmdtKanyaMahavidayalaya, Jashwantgarh, Nagaur, Rajasthan \\ ${ }^{6}$ Department of Zoology and Biotechnology, H.N.B. Garhwal University (A Central University), Srinagar \\ Garhwal, Uttarakhand, India.
}

*Corresponding Author Email id: $\underline{\text { sarveshlohan@gmail.com }}$

Received: 2.5.2021; Revised: 7.9.2021; Accepted: 9.11.2021

CSociety for Himalayan Action Research and Development

\begin{abstract}
Oroxylumindicum is a night bloomer and is pollinated naturally by bats. O. indicum, is used as one of the important ingredients in most commonly used Ayurvedic preparation, named as "Dasamula". Stem bark has anti-rheumatic properties. Bark powder infusion are diaphoretic. The Tender fruits are spasmodic carminative, and stomachic while the seeds are purgative. Root bark of sonapatha is an astringent, tonic, anti-diarrhoeal, diuretic, anodyne, and is used to cure dropsy. The Flavonoids Chrysin, oroxylin-A, Scutella in and baicalein have been found in the stem bark and leaves of this plant. This plant's seed are said to carry ellagic acid. In the current scenario, the investigation's scope is critical for commercializing this plant and knowing the physiological function of bioactive chemicals during the development of diverse organs. It may allow for the standardization of physiological maturity, which is necessary for getting high-quality raw materials for the design and manufacture of health-beneficial medications.
\end{abstract}

Keywords: Oroxylumindicum, Ayurveda, Anticancer, Flavonoids, Antioxidant, Biological activity

\section{Introduction}

Oroxylumindicum also known as the Indian trumpet tree, is a tropical tree native to India, Japan, China, Sri Lanka, and Malaysia, with the exception of the western drier areas (Deka et al. 2013). It is a glabrous, small to mediumsized tree/shrub with a branched top. The tree flowers bloom at night and is pollinated by bats naturally. Fruits of the tree have a swordlike appearance. The seeds have a long silvery wing and are numerous, flat, and small. Blossoming time is from January to March, and fruiting time from April to July (Maitreyi and Sunita, 2010a). O. indicum, is essential element in the most widely used Ayurvedic preparation known as "Dasmula". It is also in DhanawantaraGhrita, Dantyadyarista, Brahma Rasayana, and Chyavanaprasa etc. Bark powder infusions are diaphoretic. The tender fruits have spasmolytic, carminative, and stomachic properties, while the seeds are purgative. Sonapatha root bark is used to treat dropsy and is an astringent, tonic, antidiarrheal, diuretic, and anodyne. The 
Flavonoids Chrysin, oroxylin-A, Scutella in and baicalein have been found in the stem bark and leaves of this plant. This plant's seed are said to carry ellagic acid (Bisht et al, 2011; Chaudhary et al, 2020a). Recent in vivo and in vitro studies have indicated it as anti- inflammatory, anti-ulcer, immunomodulatory, anticancer, anti-oxidant, photo cytotoxic, antiproliferative, anti-arthritic, anti-microbial, anti-mutagenic and diuretic (Harminder and Chaudhary, 2011; Siddiqui et al, 2012).

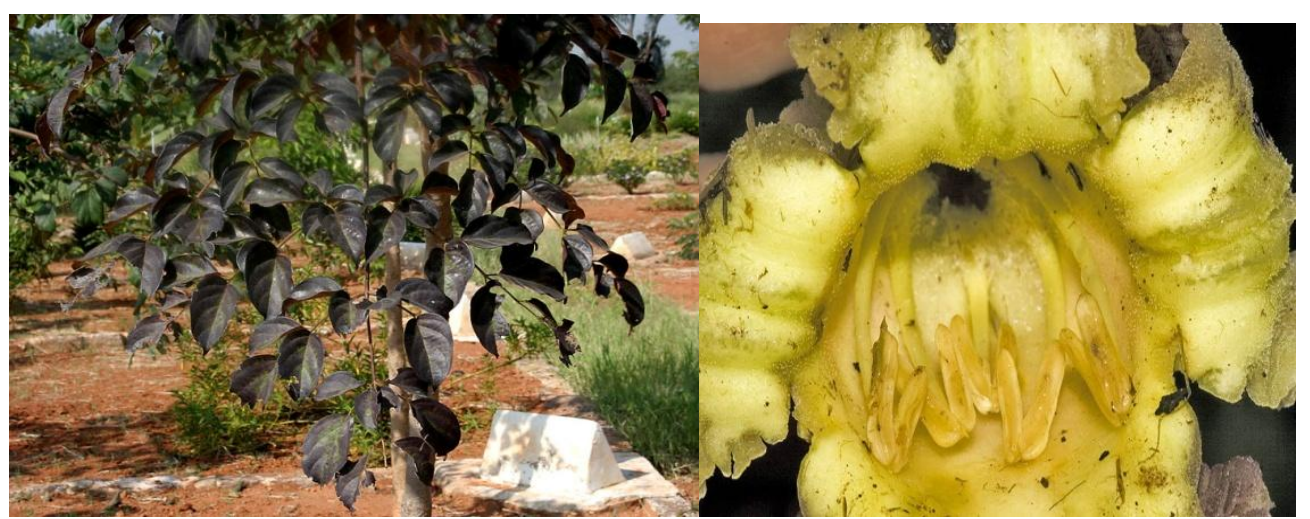

Fig.:1 leaves of Oroxylumindicum

Fig.:2 Flower with five stamen

\section{Taxonomical classification}

$\begin{array}{ll}\text { Botanical name } & \text { Oroxylumindicum } \\ \text { Kingdom } & \text { Plantae } \\ \text { Class } & \text { Magnoliophyta } \\ \text { Order } & \text { Lamiales } \\ \text { Family } & \text { Bingnoniaceae } \\ \text { Genus } & \text { Oroxylum } \\ \text { Species } & \text { Indicum }\end{array}$

Synonyms- Arthrophyllumreticulatum, Bignonia indica, Bignonia lugubris, Bignonia pentandra,

Bignonia qadripinnata, Bignonia tripinnata, Calosanthesindica, Hippoxylonindica,

Hippoxylonindica, Oroxylum flavum, Spathodeaindica.

\section{Vernacular names:}

Oroxylumindicum have many vernacular names in different languages according to distribution of Eco zone (Nadkarni et al, 1982; Deka et al. 2013 and Jagetia, 2021).

\section{Ayurvedic Shayonak}

Hindi Patrorna, Kutannat, Shallaka, Shuran, Manduk, Son, Vatuk, Arlu, Urru, Sauna

English Indian trumpet flower, Tree of Damocles, Indian Trumpet Flower, Broken Bones Plant

Chinese Butterfly tree

Gujarati Tentu

Karnataka Alangi, Tattuna, Tattuna, Tigadu., Bunepaale, Sonepatta,Patagani

Malayalam Palakappayyani, Vellapathiri, Aralu 


\section{Tamil Cari-konnai, Puta-puspam, AchiPana, Vengam}

Telugu Pampena, Manduka-parnamu, Suka-nasamu, Tundilamu

\section{Geographical Distribution}

$O$. indicum is a deciduous tree native to India, South Asia, and Southeast Asia. It can be found in India, South Asia, Southeast Asia, Sri Lanka, the Philippines, Indonesia, China, Bhutan, and Malaysia (Lawaniaet al, 2010). It was found in humid places in the forest up to 1200 masl. It may be found in Himalayan foothills, Eastern and Western Ghats, and North East India. It is most commonly seen along river banks or on hill slopes (Sharma and Sharma, 2021).

\section{Morphological Characterization}

$O$. indicum is a soft-wooded, medium-sized tree that grows to a height of 10-16 meters. The stem bark is a drab brown color. Leaves compound, 2-3 pinnate, with opposite pinnae, very broad 90-150 cm long, almost triangular in outline; primary rachis stout, cylindrical; secondary and tertiary rachis striate; petiole $5.5 \mathrm{~cm}$ long, striate; leaflets $2-4$ pairs with terminal odd one, opposite, lamina 7-17 x 3.5$10 \mathrm{~cm}$, ovate or elliptic, aovate or elliptic, apex caudate-acuminate, base rounded or asymmetric, margin entire, cretaceous, glabrous; midrib flat above; 1-2 pairs of secondary nerves arising from base; tertiary nerves broadly reticulate (Deka et al, 2013). The alternate pinnate leaves differentiate the tree. Flowers are reddish purple on the outside and pale pinkish-yellow on the inside, and they bloom in broad erect racemes. Bats are attracted to the flowers because they bloom at night and emit a heavy, stinky odor (Fujita and Tuttle, 1991). In June-July, the plant blooms, and in November, it bears fruit. The flowers have five lobes and are shaped like a bell or funnel (Kirtikar and Basu, 2001; Paranjpe, 2005). They are typically big and brightly colored, and they develop in clusters. There are four stamens on each flower. The tree has $0.33-1 \mathrm{~m}$ long and 5-10 $\mathrm{cm}$ wide swordshaped fruit pods that curled downward from the branches, resembling massive bird wings or hanging sickles or swords in the night. Within the flower, a seed pod develops (a superior ovary). The seeds are normally flat with papery wings, but an indehiscent fleshy fruit containing unwigged seeds can also be found. Externally brownish cream to yellowish brown coloured with dark brown spots on the cork, the roots are cylindrical, available in cut parts of varying length and thickness, and are $0.5-3 \mathrm{~cm}$ thick (Chaudhary et al, 2020b).

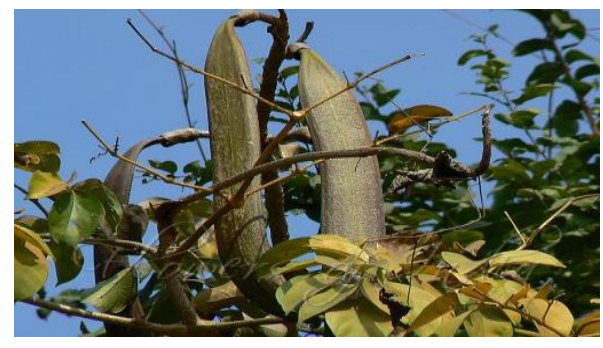

Fig.: 3 Fruit Pods of Oroxylumindicum 


\section{Phytochemical screening}

The chemical constituents of $O$. indicum have always inspired the researcher's interest. Flavones and their glycosides baicalein and scutella rein have been found in the leaves. Aloe emodin, an anthraquinonoid, is also found in the leaves (Khare, 2007 and Dey et $a l, 1978)$. Bark of the root is reported with chrysin, baicalein and oroxylin-A. Bark also gave dihydrobaicalein. Heartwood yielded beta-sitosterol and an isoflavone, prunetin. The bark also contains traces of an alkaloid, tannic acid, sitosterol and galactose (The Wealth of India, Yin et al, 2007). Its root and stem contain three flavones named oroxylin A (5, 7- dihydroxy-6-methoxyflavone), baicalein $(5,6$, 7- trihydroxyflavone) and chrysin (5, 7dihydroxyflavone). It also contains pterocarpan and rhodioside with phydroxyphenyl ethanols and cyclohexanols (Vasanth et al, 1990, Dey et al, 1978 and Theobald et al, 1981). Four flavonoids, chrysin, baicalein, baicalein-7-Oglucoside, baicalein-7-O-diglucoside (Oroxylin B) and one unknown flavonoid have also been isolated from the seeds of Oroxylumindicum (Chen et al, 2003). Seeds also contain shiny oil, the yield of which was $20 \%$ (Kirtikar and Basu, 2001).<smiles>O=C1C(=O)c2ccccc2C(=O)c2ccccc21</smiles>

Baicalein Anthraquinone

Ethno medicinal importance of Oroxylumindicum

Ayurveda's medicinal treatise dates back to the prehistoric Vedic period, and it is the oldest evidence for the use of plants as medicine. As a result, $O$. indicum has the following medicinal properties: The plant's root bark is astringent to the bowels, cooling, aphrodisiac, tonic, improves appetite, and is used to treat "vata," biliousness, fevers, bronchitis, intestinal worms, vomiting, dysentery, leucoderma, asthma, inflammation, and anal problems. It's used to treat rheumatism, diarrhoea, dysentery, and diaphoresis (Kirtikar and Basu, 2001; Jayaram and Prasad, 2008).
As a digestive tonic, a paste made from sesame oil (Sesamum indicum) and powdered root bark is used. The seeds have a purgative effect and are used to treat throat infections and hypertension when taken orally (Singh et al, 2002). The fruits are acrid, sweet, stomachic, anthelmintic, and successful in diseases of the throat and heart, piles, bronchitis, and as an expectorant; they also help with leucoderma (Chopra et al, 2002; Drury, 2006;). Snake bites are treated with leaves (Nadkarni, 1982; Khare, 2007). Externally, the leaves are used to treat a swollen spleen, as well as headaches and ulcers, and have been stated to have analgesic 
and antimicrobial properties (Drury, 2006). Fever, pneumonia, and respiratory problems are treated with the bark and seeds of the plant by various Indian tribes (Panghalet al, 2010; Patil et al, 2008). It's also used to treat a variety of stomach problems (Rout et al., 2009). Astringent, anti-inflammatory, aphrodisiac, expectorant, anthelmintic, and tonic are all uses for the root. It's also used in a nootropic formulation (Maciuket al, 2001).

$O$. indicum is a main ingredient in many popular Ayurvedic formulations, including Dasamula, Amartarista, Dantyadyarista, Narayana Taila, DhanawantaraGhrita, Brahma Rasayana, ChyavanaprasaAwaleha, and others (Balkrishna, 2005; Kunwaret al., 2009). Different parts of $O$. indicum are used in the formulation of chavanprasha and mental drugs (Laupattarakasemet al., 2003; Gupta et al., 2008).

\section{Pharmacological Properties-}

\section{1) Analgesic Activity:}

Siddiqui et al., (2012) investigated butanol extract of root bark for their analgesic activity.

Two test models were employed to determine analgesic activity; tail flick and acetic acid induced writhing reaction. The tail flick method was performed on Wistar albino rats weighing 200-250 g. Siddiqui et al., (2012) reported that the standard medicine morphine (10 mg/kg BW, i.p.) was given to one group of animals, while the other received $100 \mathrm{mg} / \mathrm{kg}$ BW p.o., One hour after administration, the rat's tail was placed on a nichrome wire of an analgesiometer, and the time it took the animal to flick its tail was recorded as reaction time.
For acetic acid-induced writhing, analgesic activity was assessed at 0 and 30 minutes; Swiss albino mice weighing 20-25 g were used. In one category, the n-butanol fraction was given $100 \mathrm{mg} / \mathrm{kg}$ BW p.o. Standard aspirin ( $25 \mathrm{mg} / \mathrm{kg} \mathrm{BW}$, i.p.) was given to the other party. Maitreyi and Sunita, (2010b) reported that the number of writhes was counted for up to 30 minutes after an injection of acetic acid 0.6 percent $\mathrm{v} / \mathrm{v}(10 \mathrm{ml} \mathrm{v} / \mathrm{v} / \mathrm{kg}$ BW, i.p.) was provided one hour after the administration. A positive analgesic response was described as a reduction in the number of writhing in either treatment relative to the vehicle-treated animal. Oral administration of n-butanol fraction significantly prolonged the reaction time in rats. Writhing was reduced by 75.93 percent when n-butanol fraction was given orally, compared to 87.05 percent when aspirin was given. The presence of flavonoids such as baicalein, ellagic acid, and biochaninA in the roots of Oroxylumindicum has been linked to the analgesic effect. (Maitreyi and Sunita, 2010b; Siddiqui et al., 2012).

\section{2) Antimicrobial Activity:}

Aliet al. (1998) reported antibacterial properties of methanolic, ethyl acetate, and ethanolic extracts of $O$. indicum. Three different gram-positive and Gram negative bacteria i.e. Bacillus subtilis, E. coli, and Pseudomonas aeruginosa were used to test. All of the extracts have remarkable antibacterial capabilities (Aliet al., 1998). Bhardwaj et al., (2018) reported that the antibacterial and antifungal activity of $O$. indicum root extracts in crude petroleum ether, 
ethyl acetate, methanolic, and also the two compounds isolated from them, 2,5-dihydroxy 6,1-dimethoxyflavonand 3,7,3',5'-tetramethoxy 4'-hydroxyflavone, was found to be moderate to strong. The study's findings supported the use of this plant against the action of microbial infections.

\section{3) Antioxidant Activity:}

Siddiqui et al., (2012) investigated various extracts of the leaves for their free radical scavenging activity in vitro. The antioxidant activity of $O$. indicum crude ethyl acetate, methanolic, and water extracts were investigated. At a concentration of $100 \mathrm{~g} / \mathrm{ml}$, the IC 50 Values for indicum leaves were 49.0, 55.0 and 55.0 respectively. Methanolic and aqueous extracts of O. indicum stem bark have also been found to have a wide range of medicinal applications. Antioxidant properties, cytotoxicity, and defense against oxidative DNA damage have all been verified, as well as ferric reducing antioxidant (FRAP), free radical (DPPH and $\mathrm{OH}-$ ) scavenging activities, and an inhibitory effect on lipid peroxidation. Both extracts were found to have significant free radical scavenging and ferric reducing properties. Both the extracts exhibited moderate levels of DNA protection against oxidative stress (Siddiqui et al., 2012).

\section{4) Anti-inflammatory Activity:}

Lalrinzualiet al., (2016) reported that antiinflammatory function of carrageenan was tested in rats using a carrageenan-induced rat paw edema model and diclofenac sodium as the standard drug. The aqueous extract of $O$. indicum was given in two doses of $150 \mathrm{mg} / \mathrm{kg}$ and $300 \mathrm{mg} / \mathrm{kg}$. When compared to the control, the paw volume was significantly reduced in a dose-dependent manner. The antiinflammatory activity of the extract was strongest at a dose of $300 \mathrm{mg} / \mathrm{kg}$. The activity produced by both doses, however, was lower than the reference norm. At 5 hours, both doses of extract had strong anti-inflammatory activity (P0.05), the extract largely suppresses the release of prostaglandin like compounds, implying that it is a prostaglandin inhibitor. Several flavonoidal have been identified as anti-inflammatory agents, and flavonoids present in plant could be the source of this action (Lalrinzualiet al., 2016).

\section{5) Anti-ulcer Activity:}

According to Khandharet al. (2008) a 50 percent alcoholic extract of the plants root bark and its various fractions, such as petroleum ether, chloroform, ethyl acetate, and n-butanol fractions, demonstrated gastro protective potential against ethanol induced gastric mucosal damage. In the Water Immersion plus Restriction Tension (WIRS) model, the n-butanol fraction was also investigated. The n-butanol fraction demonstrated the most important inhibition of gastric lesions of all of these fractions. Pretreatment with n-butanol fraction showed substantial antiulcer and antioxidant activity in gastric mucosal homogenates in the WIRSmodel, Stress-induced increase in ulcer index, lipid peroxidation, and decrease in superoxide dismutase, catalase, and lower glutathione levels were reversed in this study (Khandharet al., 2008) 


\section{6) Anti-cancer Activity:}

According to siddiquiet al., (2012) the anticancer properties of $O$. Indicum have been tested in experimental animals generated by several types of carcinogens, as well as in human cell lines. OnHep-2 cell lines, an Ethanolic extract of O. indicum was reported to have an anti-prolifrative effect. Baicalein, the most ample flavonoid found in the leaves of $O$. indicum, was extracted and evaluatedin the HL-60 cell line. According to the findings, baicalein has an anti-tumor effect on human cancer cells.

Various studies have proved anticancer potential of $O$. indicum using various models.

Narisa et al., (2006) reported that theextracted of $O$. indicum with $95 \%$ ethanol and tested for cytotoxic effects determine the antiproliferative effects on Hep2 cell lines. Cell proliferation was measured using a colorimetric method based on the ability of metabolic active cells to cleave the yellow tetrazolium salt XTT to an orange formazan dye and soluble formazan dye was directly quantified using a scanning multiwall spectrophotometer (ELISA plate reader). Ethanol exhibited cytotoxic activity against the Hep2 cell lines at a concentration of $0.05 \%$ (Narisa et al., 2006).

Roy et al., (2007) reported the effects of baicalein on the viability and induction of apoptosis in the HL-60 cell line were examined in vitro. The vitality of cells after viability after 24 hours of treatment with baicalein was determined by counting viable cells using trypan blue staining. However, at higher doses, proliferation suppression may be linked to apoptosis and dUTP nick end tagging mediated by terminal deoxynucleotidyl transferase (TUNEL). The finding suggests that baicalein possesses anti-tumor properties in human cancer cells, and $O$. indicum extract could be utilized as a cancer supplement.

Lotufoet al. (2005) found that extract $O$. Indicum was toxic to tumor cell lines. It also stop the cell cycle from progression past the first cleavage on Sea urchin eggs (IC50 = 13.5 $\mu \mathrm{g} / \mathrm{ml})$. On the basis of these data, it is possible to conclude that $O$. indicum extracts could be used as potential sources of anticancer chemicals.

\section{7) Anti-mutagenic Activity:}

In the presence of S9 mix using Salmonella typhimurium, methanol extract of plant substantially suppressed the mutagenicity of Trp-P-1 in an Ames pre-incubation procedure. The high amount $(3.95 \pm 0.43 \%$, dry weight $)$ of baicalein in the extract was linked to its effective antimutagenecity. Because it prevents N-hydroxylation of Trp-P-2, baicalein act as a desmutagen. Baicalein antimutagenic action was discovered in S-915 due to the suppression of $\mathrm{N}$-hydroxylation catalyzedby CYP-450 monooxygenases (Nakahara et al., 2001).

\section{8) Anti-helminthic Activity:}

According to the Deoriand Yadav, (2016) anthelminthic activity of $O$. indicum has been investigated in vitro. $O$. indicum'santhelminthic activity against equine 
strongly eggs were measured in vitro and compared to that of ivermectin, one of the most effective deworming agents. 0 percent hatching of eggs at a dose of 210-1 g/L Oroxylumindicum was found to have important anthelminthic activity. (Deoriand Yadav, 2016).

\section{9) Hepatoprotective Activity:}

Tenpe and Yeole, (2009) reported that the leaves of $O$. indicum are commonly used as a prophylaxis for liver disorders. Different extracts of O. indicum Vent. Had antihepatotoxic efficacy against CCl4-induced hepatotoxicity, according to Tenpe et al., 2009, Serum enzyme levels were determined after diseased animals (rats) were given 300 $\mathrm{mg} / \mathrm{kg}$ body weight of pet ether, chloroform, ethanol, and aqueous extracts. SGOT, SGPT, $\mathrm{ALP}$, and total bilirubin levels were significantly lower in all test groups, although total protein levels were significantly higher in $\mathrm{CCl} 4$ and $O$. indicum treated rats. The ethanolic extract was found to be the most efficient of all the extracts.

\section{0) Immuno stimulating Activity:}

Zaveri et al., (2006) investigated the immunomodulatory function and mode of action of the n-butanol fraction $(100 \mathrm{mg} / \mathrm{kg}$ body weight, per os, once daily for 22 consecutive days) of the root bark of $O$. indicum in rat using immune responses to sheep red blood cells (SRBC haemagglutinating antibody [HA] titer) and delayed-type hypersensitivity reactions. Treatment with the n-butanol fraction caused a substantial increase in circulating HA titers during secondary antibody responses in response to SRBC, suggesting that some aspects of the humoral response were potentiated. The treatment also caused a substantial increase in the development of paw edema, suggesting an increased host DTH response. Large reductions in whole blood Malondialdehyde (MDA) content, as well as increased activities/levels of superoxide dismutase, catalase, and decreased glutathione, demonstrated the drug's antioxidant ability. Furthermore, histopathologic examination of lymphoid tissues indicated an improvement in cellularity in the treatment population, including T-lymphocytes and sinusoids. The level of edema raised in drug-treated rats was greater than in control rats in a triple antigenmediated immunological edema model, confirming enhanced DTH reactions in response to the drug treatment. Based on these observations, an active fraction of O. indicum immunomodulatory activity may be due to its ability to improve complex immune responses (both humoral and cell-mediated), as well as its antioxidant capacity (Zaveri et al., 2006).

\section{Conclusion}

$O$. indicum is a unique plant that is commonly used in Ayurveda and Unani medicine formulations to treat infectious and degenerative diseases. Biologically active molecules' physiological and biochemical roles shift during developmental stages, according to previous studies on their isolation 
and characterization. These factors are crucial for the commercialization of this plant. It can provide an opportunity to standardize physiological maturity, which is essential for obtaining high-quality raw materials for the design and production of health-beneficial goods. Root crops are a good source of flavonoids of various kinds. Flavonoids are a significant storage component in the stem bark of O. indicum, which supports this theory. This natural scientific inquisitiveness was also ardently attended by conducting thorough investigations on chemical composition from various parts of $\mathrm{O}$. indicum, if it was also endowed with inimitable property.

\section{References}

AliRM, Houghton PJ, Raman A, Hoult JR (1998) Antimicrobial and antiinflammatory activities of extracts and constituents of Oroxylumindicum (L.) Vent. Phytomedicine. 5(5): 375-81.

Balkrishna A (2005) Ayurvedjadibootirahasya. Divyaprakasan, Divyayogmandir trust, Haridwar, Uttrakhand. p 132-136.

Bhardwaj A, Pathak A, Bhatia D, Sahoo J, Batra U, Tripathi M, Mishra TV and Choudhary P. (2018) A PhytoPharmacological Overview on Oroxylumindicum (Linn.) Vent. International Journal Advanced Research. 6(8), 291-297.

Bisht A, Anupam Z, Singh K, Gupta M, Singh $\mathrm{R}$ and Singh V (2011) Pharmacognostical studies on Oroxylumindicum (Linn.)Vent. Stem bark. Indian Journal of Natural
Products and Resources. 2(4): 472478.

Chaudhary R, Kumar S, Saini V, Bhati A and Kumar S (2020a) Evaluation of Hepatoprotective activity of OroxylumIndicumroot ethanolic extract. International Journal of Scientific Development and Research, 5(7), 206-211.

Chaudhary R, Kumar S, Saini V, Bhati A and Kumar S (2020b) Physico-Chemical Analysis and Preliminary Phytochemical Screening of OroxylumIndicum Root. International Journal of Recent Science Research, 11(06B), 38900-38905.

Chen LJ, David EG and Jones J (2003) Isolation and identification of four flavonoid constituents from the seeds of Oroxylumindicum by high speed counter-current chromatography. Journal of Chromatography A. 988(1): 95-105.

Chopra RN, Nayar SL and Chopra IC (2002) Glossary of Indian Medicinal Plants. National Institute of Science Communication and Information Resources, New Delhi, 182.

Deka DC, Kumar V, Prasad C, Kumar K, Gogoi BJ, Singh L and Srivastava RB (2013) Oroxylumindicum - a medicinal plant of North East India: An overview of its nutritional, remedial, and prophylactic properties. Journal of Applied Pharmaceutical Science. 3(1): S104-S112.

Deori K, Yadav AK (2016) Anthelmintic effects of Oroxylumindicum stem bark extract on juvenile and adult stages of Hymenolepisdiminuta (Cestoda), an in vitro and in vivo study. Parasitol Res. 115(3):1275-1285. 
Dey AK, Mukherjee P, Das PC and Chatterjee A (1978) Occurrence of Aloe-emodin in the leaves of Oroxylumindicum Vent. Indian Journal of Chemistry. 16B: 1042 .

Drury CH (2006) Ayurvedic Useful Plants of India. Asiatic Publishing House, Delhi, pp 360

Fujita MS and Tuttle MD (1991) Flying foxes (Chiroptera: Pteropodidae): threatened animals of key ecological and economic importance. Conservation Biology. 5(4): 455-463.

Gupta RC, Sharma V, Sharma N, Kumar N and Singh B (2008) In vitro antioxidant activity from leaves of Oroxylumindicum (L.) (Vent.)- A north Indian highly threatened and vulnerable medicinal plant. J Pharm Res. 1(1): 65-72.

Harminder VS and Chaudhary AK (2011) A review on the taxonomy, Ethnobotany, Chemistry and Pharmacology of Oroxylumindicum. Indian Journal of Pharmaceutical Sciences 73(5) 483490.

Jagetia GC (2021) A Review on the Medicinal and Pharmacological Properties of Traditional Ethnomedicinal Plant Sonapatha, Oroxylumindicum. Sinusitis. 5; 71-89.

Jayaram K, Prasad MNV (2008) Genetic diversity in Oroxylumindicum (L.) Vent. (Bignoniaceae), a vulnerable medicinal plant by random amplified polymorphic DNA marker. African Journal of Biotechnology, 7, 254-262.

Khandhar M, Shah MB, Santani D, Jain S (2008) Antiulcer Activity of the Root Bark of Oroxylumindicum. Against Experimental Gastric Ulcers.
Pharmaceutical Biology 44(5):363370.

Khare CP (2007) Indian Medicinal Plants: An Illustrated Dictionary. Springer Science and Business Media, LLC, New York. Pp. 453.

Kirtikar KR and Basu BD (2001) Indian Medicinal Plants. Oriental Enterprises, Dehradun. 4: 1105-1107.

Kunwar RM, Uprety Y, Burlakoti C, Chowdhary CL and Bussmann RW (2009) Indigenous Use and Ethnopharmacology of Medicinal Plants in Farwest Nepal. Ethnobotany Research \& Applications. 7: 5-28.

Lalrinzuali $\mathrm{K}$, Vabeiryureilai $\mathrm{M}$ and Jagetia GC (2016) Investigation of the AntiInflammatory and Analgesic Activities of Ethanol Extract of Stem Bark of Sonapatha Oroxylumindicum In-Vivo. International Journal of Inflammation.https://doi.org/10.1155/ 2016/8247014.

Laupattarakasem P, Houghton PJ, Hoult JR, Itharat A (2003) An evaluation of the activity related to inflammation of four plants used in Thailand to treat arthritis. J Ethnopharmacol. 85(2-3): 207-215.

Lawania RD, Mishra A and Gupta R (2010) Oroxylumindicum: A Review. Pharmacognosy Journal. 2(9): 304310.

Lotufo LVC, Khan MTH, Ather A, Wilke DV, Jimenez PC and Pessoa CA (2005) Studies of the anticancer potential of plants used in Bangladeshi folk medicine. Journal of Ethnopharmacology. 99: 21-30. 
Maciuk A, Bouchet MJ, Mazars G, UM BH, Anton R. (2001) Nootropic (medhya) plants from ayurvedic Pharmacopoeia. Etudes chimiquesetpharmacologiques. 402-11.

Maitreyi Z and Sunita J (2010) Phytopharmacogostical Studies On Root Bark Of Oroxylumindicum, Vent. International Journal of Pharmaceutical Sciences Review and Research. 4(1): 132-135.

Maitreyi NZ and Sunita MJ (2010) Antiinflammatory and analgesic activity of root bark of Oroxylumindicum, vent. Journal of Global Pharma Technology 2(4):79-87.

Nadkarni AK (1982) Indian Materia Medica. Third edition, Bombay Popular Prakashan, Mumbai 968.

Nakahara K, Onishi-Kameyama M, Ona H, Yoshida M, Trakoontivakorn G (2001) Antimutagenic activity against Trp-P1 of the edible Thai plant, Oroxylumindicum Vent. Biosci BiotechnolBiochem. 65:2358-60.

Narisa K, Jenny MW and Heather MAC (2006) Cytotoxic Effect of Four Thai Edible Plants on Mammalian Cell Proliferation. Thai Pharmaceutical and Health Science Journal. 1(3): 189195.

Panghal M, Arya1 V, YadavS, Kumar S and Yadav JP (2010) Indigenous knowledge of medicinal plants used by Saperas community of Khetawas, Jhajjar District, Haryana, India. Journal of Ethnobiology and Ethnomedicine. 6: 4.

Paranjpe P (2005) Indian Medicinal Plants. (Chaukhamba Sanskrit Pratishthan, Delhi) pp. 248-249.
Patil GG, Mali PY and Bhadane VV (2008) Folk remedies used against respiratory disorders in Jalgaon district, Maharastra. Natural Product Radiance. 7(4): 354-358.

Rout SD, Panda T and Mishra N (2009) Ethno-medicinal Plants Used to Cure Different Diseases by Tribals of Mayurbhanj District of North Orissa. Ethno Medicine. 3(1): 27-32.

Roy MK, Nakahara K, Trakoontivakorn G, Takenaka M, Isobe $S$ et al (2007) Baicalein- A flavonoid extracted from a methanolic extract of Oroxylumindicum inhibits proliferation of a cancer cell line in vitro via induction of apoptosis. Pharmazie. 62(2): 149-53.

Sharma V and Sharma O (2021) Phytochemical and Pharmacology of OroxylumIndicum Vent - Review. World Journal of Pharmaceutical and Medical Research.7(1), 95-102.

Siddiqui WA, Ahad A, Ganai AA, Sareer O, Najm MZ, Kausar MA and Mohd M (2012) Therapeutic Potential OfOroxylumindicum: A Review. Journal of Pharmaceutical Research and Opinion. 2(10): 163- 172.

Singh HB, Prasad P and Rai LK (2002) Folk Medicinal Plants in the Sikkim Himalayas of India. Asian Folklore Studies. 61: 295-310.

Tenpe CR and Yeole YG (2009) Antiinflammatory activity of aqueous extract of OroxylumindicumVent. Leaves extract- preliminary study. Pharmacologyonline. 1: 22-6.

The Wealth of India (Raw materials). Council of Scientific and Industrial Research, New Delhi. 3: 316-317. 
Theobald WL, Dassanayake MD and Fosberg MR (1981) A Revised Handbook to the Flora of Ceylon. Amerind Publishing Co. Pvt. Ltd., New Delhi.

Vasanth S, Natarajan M, Sundaresan R, Rao RB and Kundu AB (1990) Ellagic acid from Oroxylumindicum Vent. Indian Drugs. 28(11): 507.

Yin WG, Li ML and Kang C (2007) Advances in the studies of Oroxylumindicum. Zhongguo Zhong Yao Za Zhi. 32(19): 1965-1970.

Zaveri M, Gohil P and Jain S (2006) Immuno stimulant Activity of $n$-Butanol Fraction of Root Bark of Oroxylumindicum, vent. Journal of immunotoxicology. 3(2); 83-99. 